\title{
Construction machinery hire rates deviation in Malaysia: an inflation rate effect analysis
}

\author{
Muhammad Ali Musarat (Main Author) \\ Department of Civil and Environmental Engineering, Universiti Teknologi PETRONAS \\ 32610, Tronoh (Malaysia) \\ muhammad_19000316@utp.edu.my
}

Wesam Salah Alaloul (Corresponding Author)

Department of Civil and Environmental Engineering, Universiti Teknologi PETRONAS

32610, Tronoh (Malaysia)

wesam.alaloul@utp.edu.my

\section{S. Liew}

Department of Civil and Environmental Engineering, Universiti Teknologi PETRONAS

32610, Tronoh (Malaysia)

shahir_liew@utp.edu.my

Manuscript Code: 14470

Date of Acceptance/Reception: 07.04.2021/25.05.2020

DOI: $10.7764 /$ RDLC.20.1.91

\begin{abstract}
Machinery has been used in the construction industry in both small- and large-scale projects for a long time. Machinery is one of the main resources of any construction projects and rates deviation within the hiring of the machinery can result in cost overrun of the project. This study has been conducted to deal with the issue of deviating the machinery hire rates in the construction industry. The study accesses the machinery hire rates and aims to investigate the percentage deviation from 2013 to 2018. In this regard, statistical analysis was conducted to identify the influence of the inflation rate in deviating the machinery hire which results in cost overrun. Also, the interconnectivity of machinery hire rates was evaluated through the correlation coefficient. The analysis shows that the inflation rate possesses a weak relationship with nine and a moderate relationship with five machinery hire rates. However, the interconnectivity of the machinery hire rates was strongly correlated with each other, which emphasize that a change due to the influential factor will affect all the rates and can cause cost overrun. It is therefore recommended to observe other factors which deviate the machinery hire rates within the construction industry.
\end{abstract}

Keywords: machinery hire rates, percentage deviation, inflation rate, correlation coefficient, construction industry.

The construction industry is counted as one of the largest industries and has a vital role in developing the country's economy. A high capital, developing processes and the latest technologies involved in the projects has boost up the construction industry. However, due to various management and financial issues, construction projects are marked with low performance (Alaloul et al., 2020; Erusta \& Sertyesilisik, 2019; Le et al., 2020; Musarat \& Ahad, 2016; Ranjithapriya \& Arulselvan). Usually, the risk of cost overrun is involved in the construction projects which is major distress for the stakeholders (Abd Rahman, 2020; Alaloul et al., 2021; Jaya et al., 2021; Le et al., 2020). Project success can only be achieved if the project budget is viable. Therefore, it is crucial to forecast the budget accurately. Money, materials, manpower and machinery are the essential resources used in construction projects. Thus, it is essential to find out the effect of these resources on deviating the project budget (Alaloul et al., 2019b; Bayram \& Al-Jibouri, 2016; Catalão et al., 2019; Firouzi et al., 2016; Mashwama et al., 2016; Memon et al., 2014; Musarat et al., 2021).

Cost overrun is a global issue where out of ten around nine of the construction projects are facing this issue (Aljohani et al., 2017). The variation in the initial budget and the final completing budget ranges from $21 \%$ to $55 \%$ (Khodeir \& El Ghandour, 2019). That is why calculating an exact budget is crucial in achieving project success, as initially, decisions need to be taken on the accessible cost data (Musarrat et al., 2017; Paraskevopoulou \& Benardos, 2013). Various researchers worked on cost overrun matter to eliminate it from the construction project, however, it still exists (Aljohani, 2020; Assaad et al., 2020; Klakegg \& Lichtenberg, 2016; Musarat et al., 2020b; Musarat et al., 2020c; Paul \& Saigal; Rashid, 2020). Most of the construction projects are at greater risk due to the cost overrun resulting in the unsuccessful completion of the projects by exceeding the budget (Memon et al., 2013).

Cost overrun becomes a common phenomenon in Malaysian construction projects. It has been mainstreamed that more than half of the construction projects (55\%) faces cost overruns (Shehu et al., 2014). Regrettably, Malaysia's 
construction industry showing low performance to encounter the cost overrun where the average overrun is $5-10 \%$ of the initial price. On the other hand, $53.2 \%$ of the public sector and $62.8 \%$ of private-sector construction projects are over-budgeted (Abdul Rahman et al., 2012; Endut et al., 2009; Sohu et al., 2018). Even in Malaysia, construction projects are facing cost overrun and machinery rates are considered as one of the critical factors (Memon et al., 2014). A project is considered unsuccessful if it does not meet the budget and face a cost overrun. There could be many possible reasons like change order, social and technical factors, shortage of machinery, or changes in the rates of the machinery. Machinery is an important resource of any construction project and with advancement, the demand for machinery is getting higher (Alaloul et al., 2019a; Alinaitwe et al., 2013; Altaf et al., 2019; Enshassi et al., 2009b).

Table 1 highlights the cost overrun issue which was identified by various researchers through different adopted methods. In the mentioned studies the inflation rate is the ultimate cause of the cost overrun is which affects construction projects all over the world.

Table 1. Cost overrun in various regions. (Self-Elaboration).

\begin{tabular}{cllc}
\hline S. No & Study Area & \multicolumn{1}{c}{ Method } & Author \& Year \\
\hline 1 & United States & Cost escalation of the previous project & Leavitt et al. (1993) \\
2 & UK & Relative Importance Index (RII) & Olawale and Sun (2010) \\
3 & UAE & Weighted score method & Johnson and Babu (2018) \\
4 & Afghanistan & Relative Importance Index (RII) & Niazi and Painting (2017) \\
5 & Zambia & The average weighted perceived significance & Kaliba et al. (2009) \\
6 & Nigeria & Regression Analysis & Oghenekevwe et al. (2014) \\
& & Severity Index & Amusan et al. (2018) \\
7 & India & Comparison of the budgeted and actual cost & Goyal (2017) \\
& & of a project to calculate cost overrun & Tang (2014) \\
8 & Malaysia & Bounds Testing Approach & Frequency Index \\
9 & Uganda & Relative Importance Index (RII) & Haslinda et al. (2018) \\
10 & Palestine & Relative Importance Index (RII) & Alinaitwe et al. (2013) \\
11 & Vietnam & Spearman's rank correlation test & Enshassi et al. (2009a) \\
12 & Egypt & Relative Importance Index (RII) & Le-Hoai et al. (2008) \\
\hline & & & Aziz (2013) \\
\hline
\end{tabular}

Hence, it is evident that the reason behind the cost overrun is greatly due to the inflation rate which changes annually. With time the inflation rate changes, leaving an adverse effect on the project cost (Jaya et al., 2021; Musarat et al., 2020a). The project cost gets affected when machinery rates changes and the reason behind it is the inflation rate (Alinaitwe et al., 2013; Amusan et al., 2018; Olawale \& Sun, 2010). While making a budget for the construction project machinery rates are also incorporated which get affected due to the inflation rate. Therefore, this study aims to examine the changing trend of machinery hire rates and the cause behind it in the Malaysian construction industry. Statistical analysis was performed on individual machinery hire rates to observe the influence of the inflation rate in deviating the rates. Moreover, how the machinery hire rates are interconnected is also evaluated. The study is novel in terms of the relationship investigation which can set a benchmark to evaluate the issue in ongoing construction projects.

Methodology

The methodology of this research is divided into four phases. In the first phase machinery hire rates data was collected, then the arithmetic mean and the standard deviation was calculated for each rate on the available data from 2013 to 2018. In the second phase percentage deviation of the machinery hire rates were calculated to observe the drift of the data. In the third phase, statistical analysis, i.e. correlation test was performed in which a relationship was observed between machinery hire rates and the inflation rate. Lastly, the interconnectivity of the machinery hire rates was determined with the same correlation test. The flowchart of this research is provided in Figure 1 : 


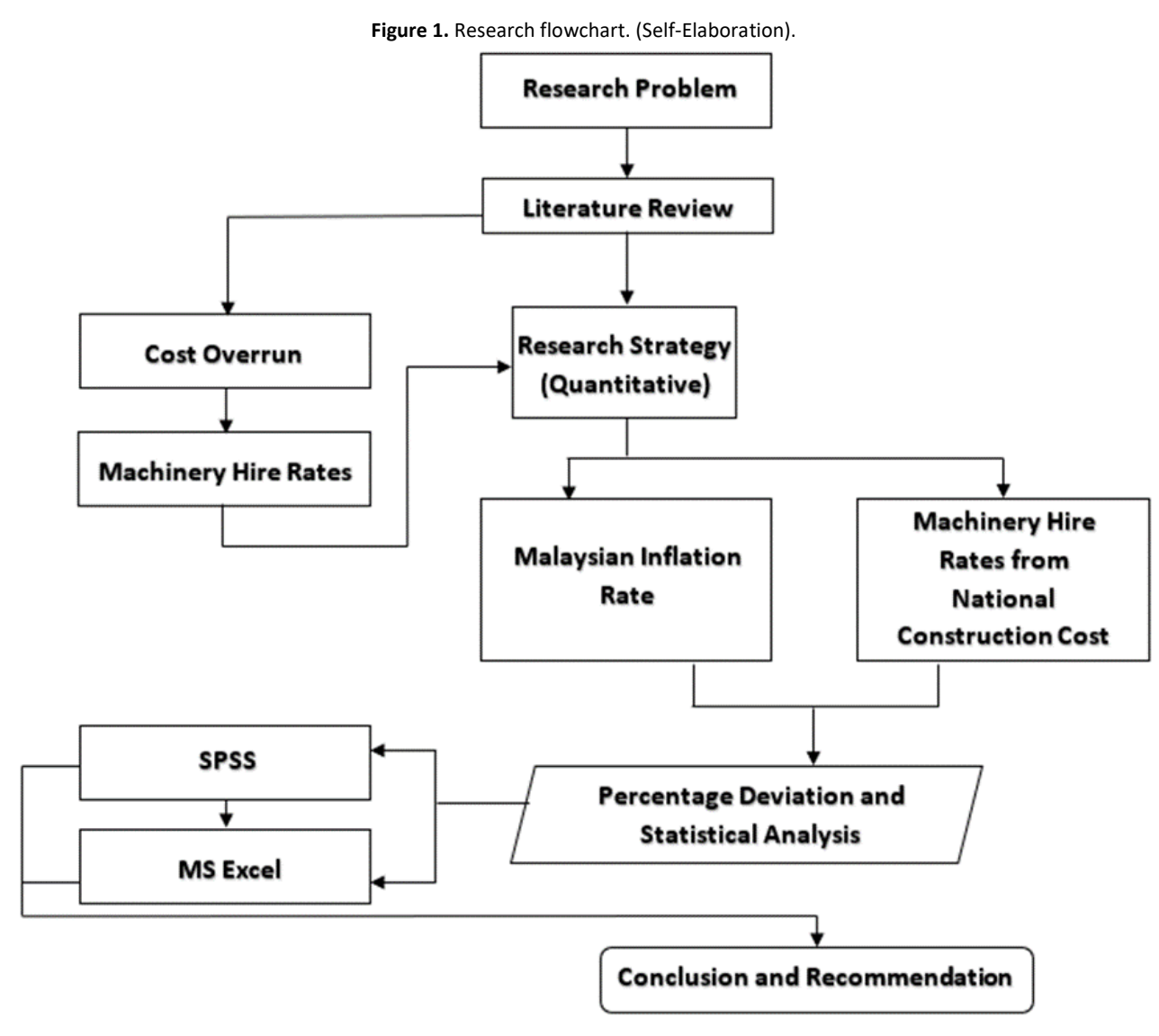

\section{Data collection}

Machinery hire rates data was taken for WP Kuala Lumpur, Malaysia from the National Construction Cost Centre (N3C, 2019), while the inflation rate data was taken from the webpage of Statista (Statista, 2019). The collected data was comprised of Excavator, Dozer, Motor Grader, Lorry and Crane which was further categorized into fourteen subtypes by the concerned department. The reason why only five machinery hire rates were taken is that they were the only types that were available from 2013 to 2018 at the time of conducting this research.

\section{Data analysis}

Initially arithmetic mean and standard deviation of the machinery hire rates were computed to observe its central value and how much they are spread out from the mean. To examine the thrust of the rates, the percentage deviation of the machinery hire rates were calculated using Equation 1:

$$
\text { Percentage deviation }=\frac{(\text { Current } \text { year }- \text { Previous year })}{\text { Previous year }} \times 100
$$

Once the percentage deviations of machinery hire rates were calculated, a statistical analysis was performed with the help of the Statistical Package for Social Sciences (SPSS-20). This test shows whether the inflation rate deviates the machinery hire rates or not. Also, how the machinery hire rates are interconnected was examined by using the same test. The correlation coefficient value should always be in between -1 to +1 in which a positive value on the scale of 0.00 -0.19 possess a very weak relationship, a value from $0.20-0.39$ possess a weak relationship, a value from $0.40-0.59$ possess moderate relationship, a value from $0.60-0.79$ possess a strong relationship and a value from $0.80-1.0$ possess a very strong relationship. The same value scale is considered for the negative correlation coefficient (Fulton, 2019; Samuel \& Okey, 2015).

The inflation rate which is an independent variable was denoted by " $x$ ", whereas the dependent variable, which is the machinery hire rates, was denoted by " $y$ ". The rates were plotted in the scatter graph as shown in Figure 2 to observe the linearity or nonlinearity of the data, as the correlation test varies for both types of data. If the data possess a linear relationship then the Pearson correlation test is performed, however, in the case of a nonlinear relationship, Spearman correlation is recommended (Kornbrot, 2005; Minitab). 
Figure 2. Scatter graph of machinery hire rates and the inflation rate. (Self-Elaboration).

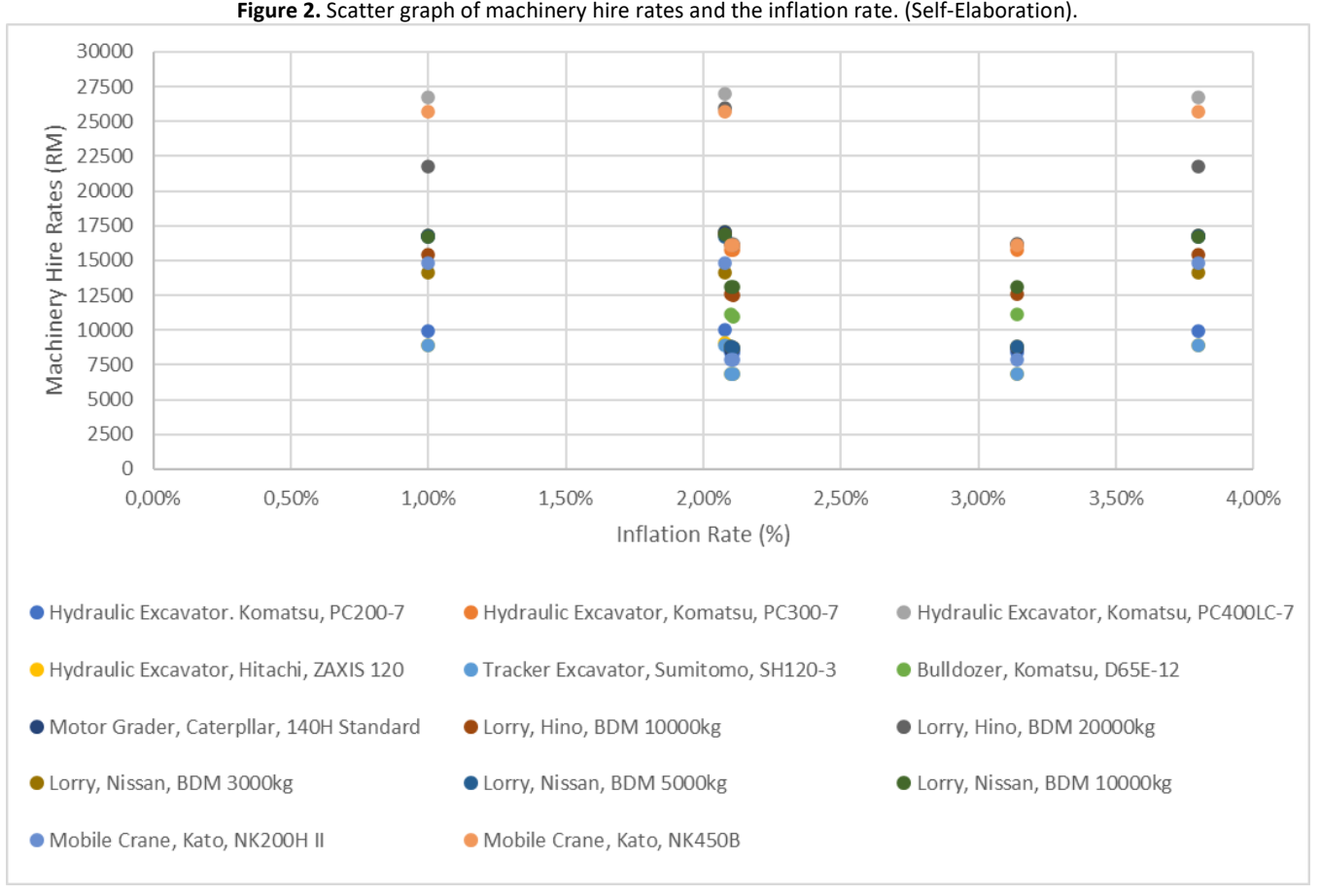

From Figure 2, it can be observed that the data possess a nonlinear relationship as all the observations of machinery hire rate are at different intervals without forming a straight linear line. Therefore, the Spearman correlation test was performed.

This section illustrates the results of arithmetic mean, standard deviation, percentage deviation and the correlation coefficient of the fourteen subtypes of machinery hire rates.

\section{Machinery hire rates}

The detailed machinery hire rates with arithmetic mean and standard deviation are given in Appendix A. The changing trend of machinery hire rates can be seen in Figure 3. 
Figure 3. Average machinery hire rates per year. (Self-Elaboration).

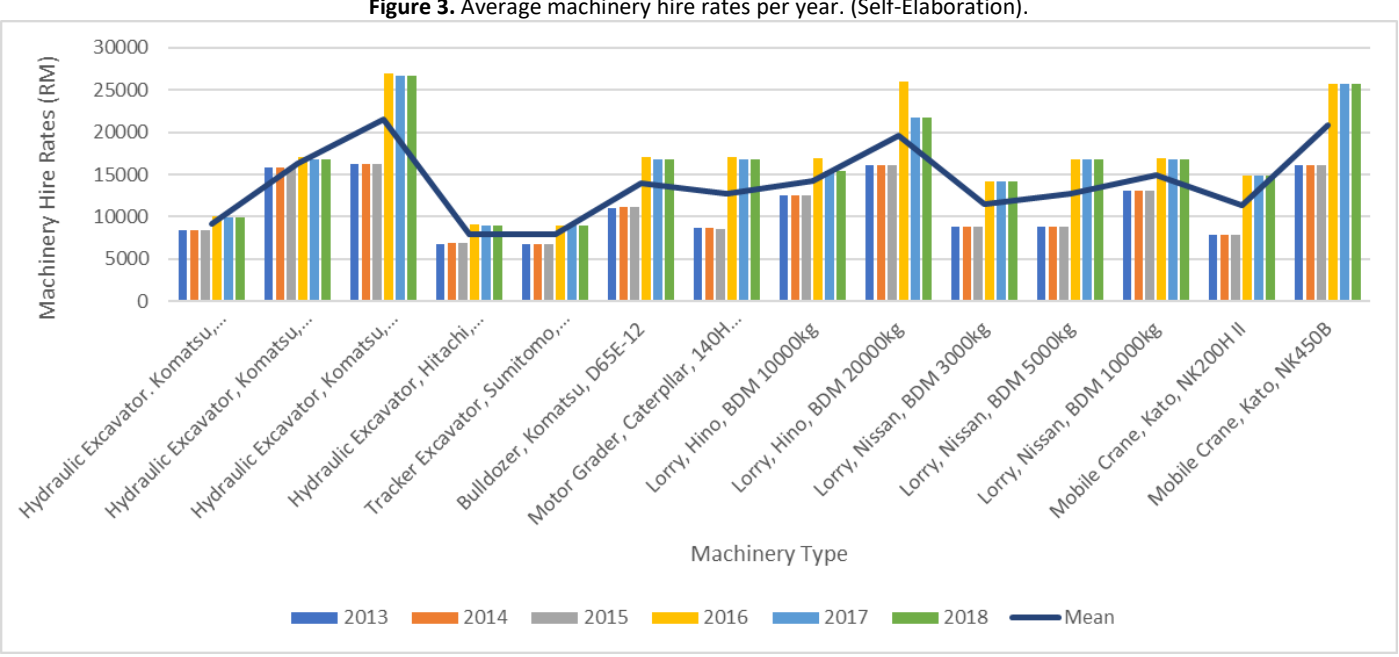

Although an increase was recorded in the rates, the pattern was unique. The rates got an increase but with a gap of three years. From the year 2013 to 2015 the rates were nearly the same and got an increase in 2016 which forms the same pattern of constant rates till 2018.

Figure 4 shows the standard deviation of all the machinery hire rates. The highest deviation was observed for "Hydraulic Excavator, Komatsu, PC400LC-7" and "Mobile Crane, Kato, NK450B". The lowest deviation was observed for "Hydraulic Excavator, Komatsu, PC300-7" and "Hydraulic Excavator, Komatsu, PC200-7". Whereas, all other machinery hire rates were showing a moderate deviation in the rates.

Figure 4. Standard deviation of machinery hire rates. (Self-Elaboration).

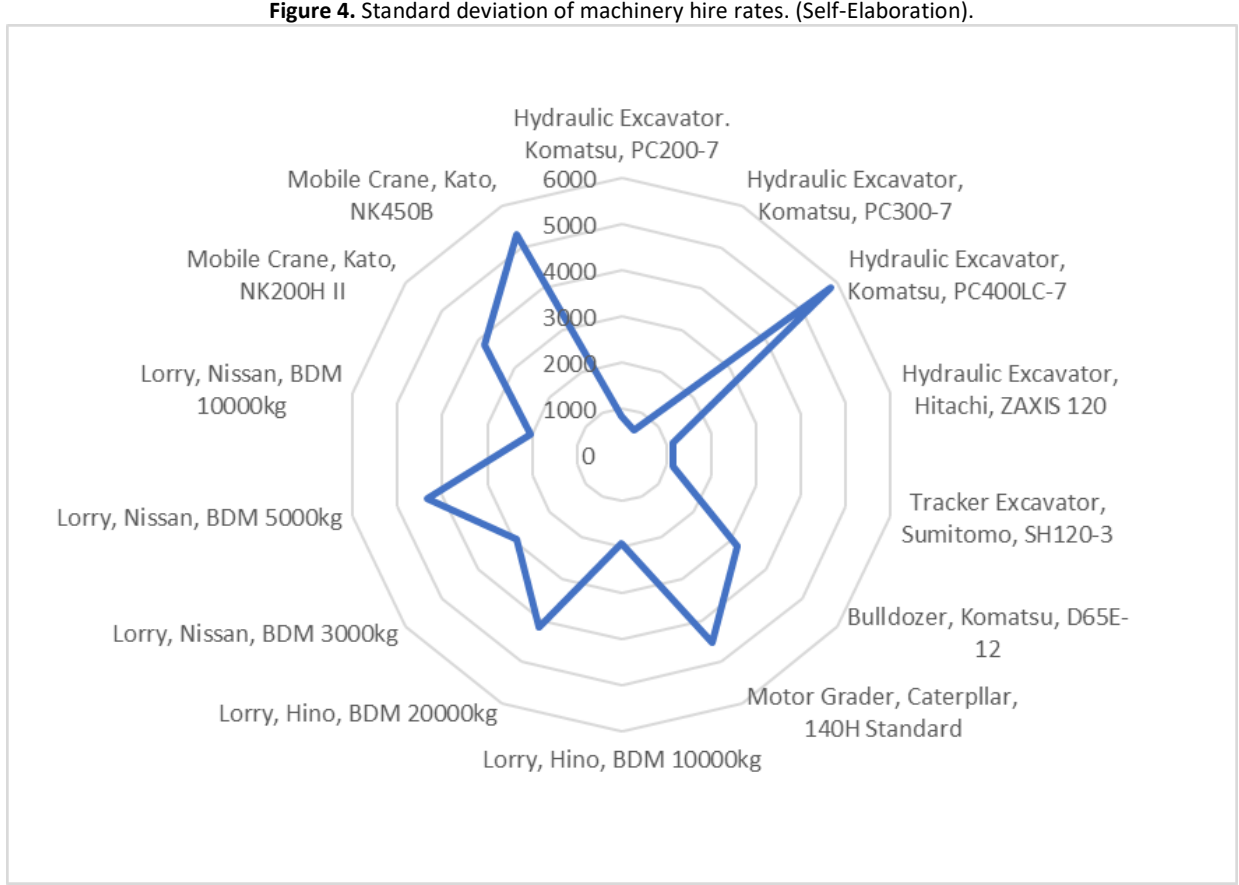




\section{Percentage deviation calculation}

The percentage deviation was computed for all the machinery hire rates by using Equation 1 which are given in Appendix B. The deflection of the rates was observed in a positive as well as in a negative manner. The positive deviation shows an increase, whereas the negative deviation shows a decrease in the rates as compared to the previous year. The deviations in each machinery hire rates are provided in Figure 5 and 6.
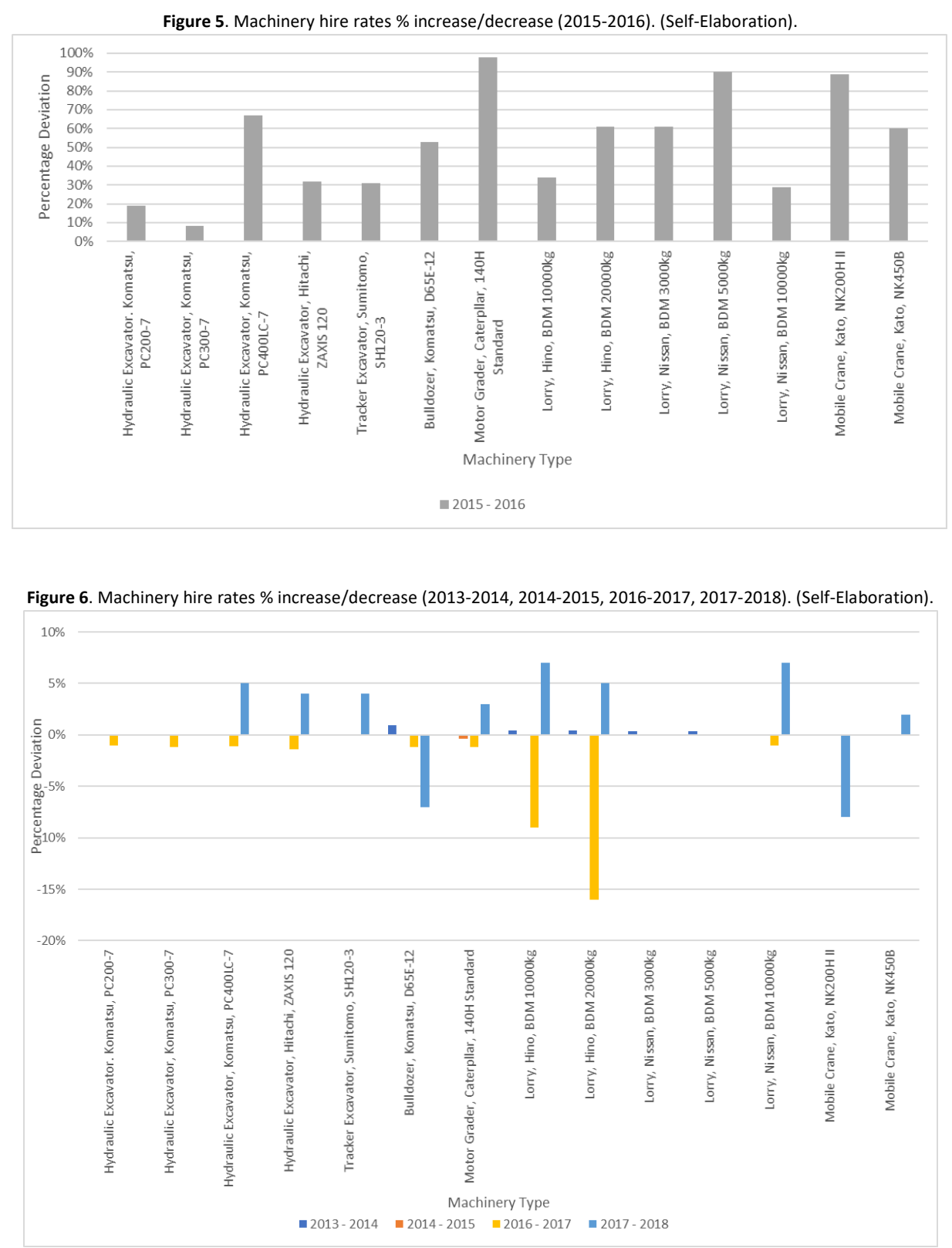

Due to a significant difference in the values and for better representation, percentage deviations were provided separately in two figures. From Figure 5 it can be observed that the deviation mainly occurs during the year $2015-2016$. Whereas, a very low deviation was recorded in the year 2016 - 2017 as shown in Figure 6. Most of the machinery hire rates showed a $0 \%$ deviation during the study period. The overall deviation of machinery hire rates was also calculated. The highest positive deviation was observed as 52\% in 2015 - 2016. In $2014-2015$ and 2017 - 2018, 0\% deviation was observed. A negative deviation was also observed as $-2 \%$ in $2016-2017$. While in $2013-2014$ the deviation was only $0.20 \%$.

\section{Spearman correlation}

Inflation with Machinery Hire Rates: Several researchers emphasized that the inflation rate is the influential factor in changing the machinery hire rates (Alinaitwe et al., 2013; Amusan et al., 2018; Olawale \& Sun, 2010). To observe the 
phenomena in the Malaysian construction industry, the Spearman correlation test was conducted to determine whether the inflation rate deviates the machinery hire rates or not. The Malaysian inflation rate was transformed from percentage value to percentage deviation so that all the data possesses the same pattern which can easily detect the relationship between inflation rate and machinery hire rates. The inflation rate and its yearly percentage deviation are provided in Figure 7 and the summary of the overall results of Spearman correlation is provided in Table 2.

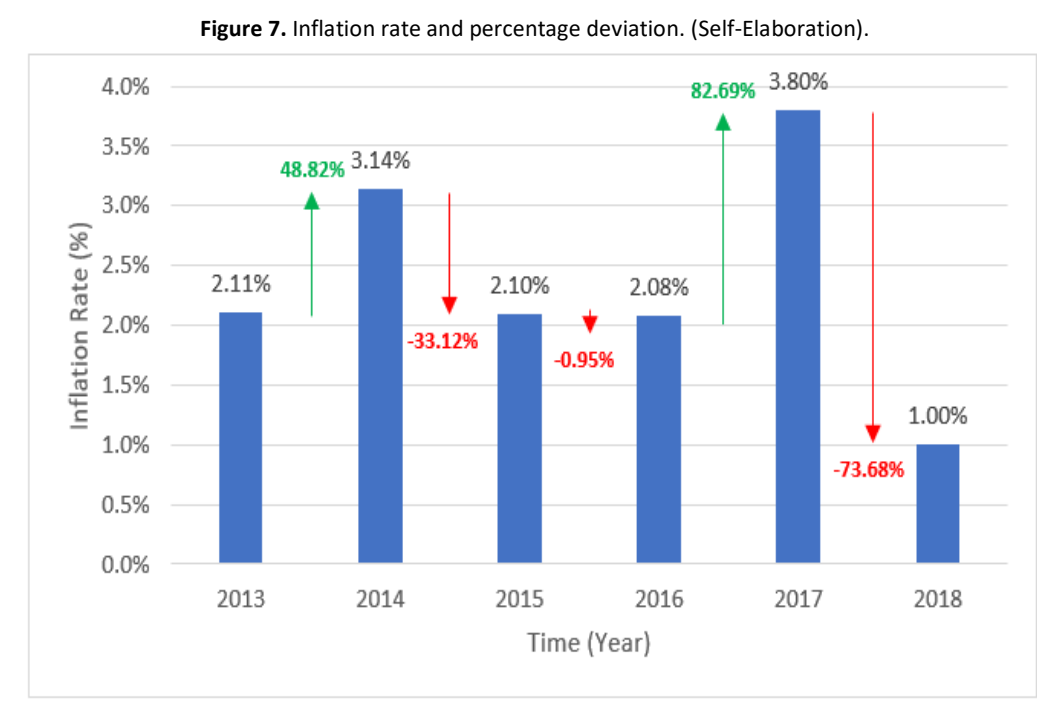

\begin{tabular}{clcc}
\multicolumn{4}{c}{ Table 2. Summary of spearman correlation. (Self-Elaboration). } \\
\hline S. No & \multicolumn{2}{c}{ Correlation Coefficient } & Category \\
\hline & Relationship & Range & Machinery \\
1 & Very Weak & $0.00-0.19$ & 6 \\
2 & Weak & $0.20-0.39$ & 3 \\
3 & Moderate & $0.40-0.59$ & 5 \\
4 & Strong & $0.60-0.79$ & 0 \\
5 & Very Strong & $0.80-1.0$ & 0 \\
\hline
\end{tabular}

It can be observed from Table 2 that all the machinery hire rates lie on the scale of very weak, weak and moderate relationship. Not a single machinery showed a strong correlation with the inflation rate. The individual results of each machinery hire rates are provided in Table 3.

Table 3. Spearman correlation coefficient (inflation with machinery). (Self-Elaboration).

\begin{tabular}{clc}
\multicolumn{4}{c}{ Table 3. Spearman correlation coefficient (inflation with machinery). (Self-Elaboration). } \\
\hline S. No & \multicolumn{1}{c}{ Types of Machine } & \multicolumn{1}{c}{ Spearman Correlation Coefficient } \\
\hline 1 & & \multicolumn{1}{c}{ Excavator } \\
1.1 & Hydraulic Excavator, Komatsu, PC200-7 & -0.447 \\
1.2 & Hydraulic Excavator, Komatsu, PC300-7 & -0.447 \\
1.3 & Hydraulic Excavator, Komatsu, PC400LC-7 & -0.447 \\
1.4 & Hydraulic Excavator, Hitachi, ZAXIS 120 & -0.447 \\
1.5 & Tracker Excavator, Sumitomo, SH120-3 & 0.000 \\
2 & Dozer & \\
\hline 2.1 & Bulldozer, Komatsu, D65E-12 & -0.154 \\
\hline 3 & & -0.359 \\
\hline 3.1 & Motor Grader, Caterpillar, 140H Standard & \\
\hline 4.0 & Lorry & -0.154 \\
\hline 4.1 & Lorry, Hino, BDM 10000kg & -0.154 \\
4.2 & Lorry, Hino, BDM 20000kg & 0.224 \\
4.3 & Lorry, Nissan, BDM 3000kg
\end{tabular}




\begin{tabular}{clc}
\hline 4.4 & Lorry, Nissan, BDM 5000kg & 0.224 \\
4.5 & Lorry, Nissan, BDM 10000kg & -0.447 \\
\hline 5 & Crane & \\
\hline 5.1 & Mobile Crane, Kato, NK200H II & 0.000 \\
5.2 & Mobile Crane, Kato, NK450B & 0.000 \\
\hline
\end{tabular}

Table 3 indicates that none of the machinery categories shows an acceptable relationship between the machinery hire rates with the inflation rate. The highest positive correlation was shown by two subtypes of "Lorry", whereas, the highest negative correlation was shown by four subtypes of "Excavators" and 1 subtype of "Lorry". Overall, no individual machinery is showing a strong correlation, indicating that the inflation rate is not influential in deviating the machinery hire rates. However, the scenario could be different if the number of observations is more, and the correlation test is performed directly between the machinery hire rates and the inflation rate instead of calculating the percentage deviation. As few of the machinery hire rates showed a moderate relationship, therefore, it requires further investigation with larger-scale data.

\section{Correlation among machinery hire rates}

To observe how machinery, hire rates are interconnected, a correlation coefficient was also calculated among the different types of machinery. Based on the Spearman correlation, the coefficients are provided in Table 4. 
Table 4. Spearman correlation coefficient (among machinery). (Self-Elaboration).

\begin{tabular}{|c|c|c|c|c|c|c|c|c|c|c|c|c|c|c|}
\hline S. No & 1.1 & 1.2 & 1.3 & 1.4 & 1.5 & 2.1 & 3.1 & 4.1 & 4.2 & 4.3 & 4.4 & 4.5 & 5.1 & 5.2 \\
\hline 1.1 & - & 1.000 & 0.918 & 0.918 & 0.750 & 0.671 & 0.894 & 0.894 & 0.894 & 0.750 & 0.750 & 0.918 & 0.500 & 0.750 \\
\hline 1.2 & 1.000 & - & 0.918 & 0.918 & 0.750 & 0.671 & 0.894 & 0.894 & 0.894 & 0.750 & 0.750 & 0.918 & 0.500 & 0.750 \\
\hline 1.3 & 0.918 & 0.918 & - & 1.000 & 0.918 & 0.359 & 0.975 & 0.975 & 0.975 & 0.574 & 0.574 & 1.000 & 0.229 & 0.918 \\
\hline 1.4 & 0.918 & 0.918 & 1.000 & - & 0.918 & 0.359 & 0.975 & 0.975 & 0.975 & 0.574 & 0.574 & 1.000 & 0.229 & 0.918 \\
\hline 1.5 & 0.750 & 0.750 & 0.918 & 0.918 & - & 0.224 & 0.894 & 0.894 & 0.894 & 0.500 & 0.500 & 0.918 & 0.250 & 1.000 \\
\hline 2.1 & 0.671 & 0.671 & 0.359 & 0.359 & 0.224 & - & 0.400 & 0.400 & 0.400 & 0.894 & 0.894 & 0.359 & 0.894 & 0.224 \\
\hline 3.1 & 0.894 & 0.894 & 0.975 & 0.975 & 0.894 & 0.400 & - & 1.000 & 1.000 & 0.671 & 0.671 & 0.975 & 0.224 & 0.894 \\
\hline 4.1 & 0.894 & 0.894 & 0.975 & 0.975 & 0.894 & 0.400 & 1.000 & - & 1.000 & 0.671 & 0.671 & 0.975 & 0.224 & 0.894 \\
\hline 4.2 & 0.894 & 0.894 & 0.975 & 0.975 & 0.894 & 0.400 & 1.000 & 1.000 & - & 0.671 & 0.671 & 0.975 & 0.224 & 0.894 \\
\hline 4.3 & 0.750 & 0.750 & 0.574 & 0.574 & 0.500 & 0.894 & 0.671 & 0.671 & 0.671 & - & 1.000 & 0.574 & 0.750 & 0.500 \\
\hline 4.4 & 0.750 & 0.750 & 0.574 & 0.574 & 0.500 & 0.894 & 0.671 & 0.671 & 0.671 & 1.000 & - & 0.574 & 0.750 & 0.500 \\
\hline 4.5 & 0.918 & 0.918 & 1.000 & 1.000 & 0.918 & 0.359 & 0.975 & 0.975 & 0.975 & 0.574 & 0.574 & - & 0.229 & 0.918 \\
\hline 5.1 & 0.500 & 0.500 & 0.229 & 0.229 & 0.250 & 0.894 & 0.224 & 0.224 & 0.224 & 0.750 & 0.750 & 0.229 & - & 0.250 \\
\hline 5.2 & 0.750 & 0.750 & 0.918 & 0.918 & 1.000 & 0.224 & 0.894 & 0.894 & 0.894 & 0.500 & 0.500 & 0.918 & 0.250 & - \\
\hline
\end{tabular}

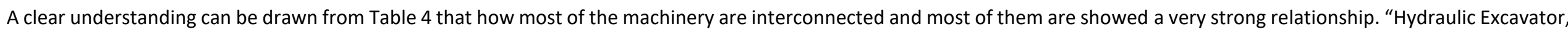

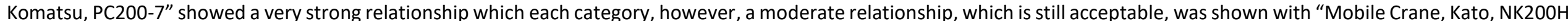

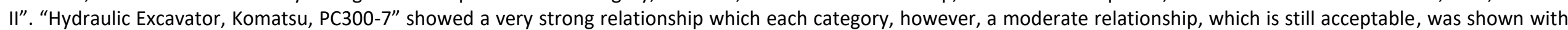

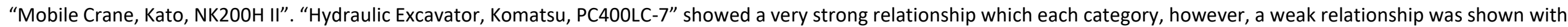
"Bulldozer, Komatsu, D65E-12" and "Mobile Crane, Kato, NK200H II".

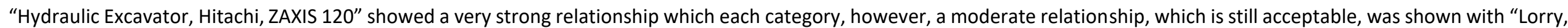

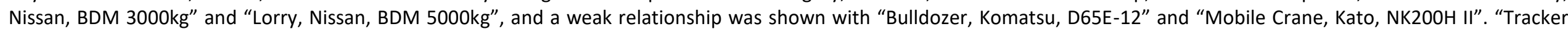
Excavator, Sumitomo, SH120-3" showed a very strong relationship which each category, however, a moderate relationship, which is still acceptable, was shown with 
"Lorry, Nissan, BDM $3000 \mathrm{~kg}$ " and "Lorry, Nissan, BDM 5000kg", and a weak relationship was shown with "Bulldozer, Komatsu, D65E-12" and "Mobile Crane, Kato, NK200H II".

"Bulldozer, Komatsu, D65E-12" showed a strong relationship with a few categories, however, a moderate relationship was observed with "Motor Grader, Caterpillar, 140H Standard", "Lorry, Hino, BDM 10000kg" and "Lorry, Hino, BDM $20000 \mathrm{~kg}$ ", and a weak relationship was observed with "Lorry, Nissan, BDM 10000kg" and "Mobile Crane, Kato, NK450B". "Motor Grader, Caterpillar, 140H Standard" showed a strong relationship with most of the categories, however, a weak relationship was observed with "Mobile Crane, Kato, NK200H II". "Lorry, Hino, BDM 10000kg" showed a strong relationship with most of the categories, however, a weak relationship was observed with “Mobile Crane, Kato, NK200H II". "Lorry, Hino, BDM $20000 \mathrm{~kg}$ " showed a strong relationship with most of the categories, however, a weak relationship was observed with "Mobile Crane, Kato, NK200H II".

"Lorry, Nissan, BDM 3000kg" showed a strong relationship with most of the categories, however, a moderate relationship, which is still acceptable, was shown with "Lorry, Nissan, BDM 10000kg" and "Mobile Crane, Kato, NK450B". "Lorry, Nissan, BDM 5000kg" showed a strong relationship with most of the categories, however, a moderate relationship, which is still acceptable, was shown with "Lorry, Nissan, BDM 10000kg" and "Mobile Crane, Kato, NK450B". "Lorry, Nissan, BDM $10000 \mathrm{~kg}$ " showed a strong relationship with most of the categories, however, a weak relationship was observed with "Mobile Crane, Kato, NK200H II". Overall, "Mobile Crane, Kato, NK200H II" showed a moderate and a weak relationship with most of the categories.

Most of the Spearman correlation coefficient values are showing a strong relationship which indicates that whatever the influencing factor is, the response of the machinery will be in the same direction. Hence, the situation is a bit more critical as with time, if the inflation rate strike with more intensity, the whole project may suffer just because of the fluctuation of the machinery hire rates. However, further investigation is required and instead of only determining the inflation rate impact on larger observations, the impact of oil prices also needs to determine. It is easily notable that with time oil prices in the market changes drastically. The change in the oil prices can directly affect the machinery hire rates which may result in cost overrun. However, this phenomenon requires further scientific research.

Machinery hire rates are significant for budget development in construction projects. The rates are deviating on annual basis which are ignored in a time of budget development, thus leads towards the project cost overrun. The following are the outcome of the analysis:

- Based on the plotted scatter graph, a nonlinear relationship was observed in machinery hire rates and the inflation rate from the year 2013 to 2018.

- The highest standard deviation was observed for "Hydraulic Excavator, Komatsu, PC400LC-7" and "Mobile Crane, Kato, NK450B".

- In most of the machinery hire rates an increasing trend was observed but with a pattern where the rates were constant in the year 2013 - 2015 and 2016 - 2018, and the only increase occurred was in 2016.

- Based on the percentage deviation calculation the highest deviation recorded was in the year 2016 - 2017 with an increase of $82.67 \%$. In other years, the deviation was very less and near to zero.

- Spearman correlation results show that the inflation rate is moderately affecting the machinery hire rates where none of the categories shows a strong relationship.

- Spearman correlation results also show that most of the machinery are strongly correlated with each other, except for "Mobile Crane, Kato, NK200H II", which showed a moderate and weak relationship with most of the machinery category.

- Overall, this scenario highlights the importance of the machinery hire rates in the construction industry and how they can affect the construction project.

- This study needs further investigation for the possible factors that could be deviating the machinery hire rates.

The analysis is based on the limited amount of data, i.e. from the year 2013 to 2018 , as the past machinery hire rates were not available. The study can further be extended by considering any other developing country in which it is easy to get the past data, as the results can significantly change by increasing the study years. It is evident that over time the rates changes, therefore along with the inflation rate, other influencing factors such as oil prices needs to be evaluated further. 


\begin{tabular}{|c|c|c|c|c|c|c|c|c|c|c|c|c|c|}
\hline $\begin{array}{l}\text { S. } \\
\text { No }\end{array}$ & $\begin{array}{l}\text { Type of } \\
\text { Machine }\end{array}$ & $\begin{array}{l}\frac{0}{C} \\
\frac{C}{\pi} \\
\frac{D}{D}\end{array}$ & $\begin{array}{l}\overline{0} \\
\frac{0}{2} \\
\sum\end{array}$ & 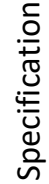 & $\begin{array}{l}\vec{T} \\
\frac{ \pm}{0} \\
\frac{0}{\pi} \\
0\end{array}$ & $\stackrel{m}{\stackrel{\sim}{\sim}}$ & 穴 & $\stackrel{\text { ñ }}{\circ}$ & $\begin{array}{l}0 \\
\stackrel{\nu}{N}\end{array}$ & नें & $\stackrel{\infty}{\circ}$ & $\begin{array}{l}\frac{c}{\overparen{D}} \\
\stackrel{\mathbb{d}}{\Sigma}\end{array}$ & 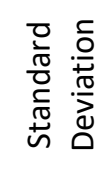 \\
\hline
\end{tabular}

\begin{tabular}{|c|c|c|c|c|c|c|c|c|c|c|c|c|c|}
\hline 1 & & & & & & & rato & & & & & & \\
\hline 1.1 & $\begin{array}{l}\text { Hydraulic } \\
\text { Excavator }\end{array}$ & 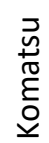 & $\begin{array}{l}\text { ò } \\
\text { ঠે }\end{array}$ & 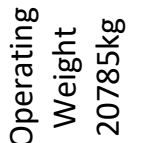 & $\begin{array}{l}\text { ñ } \\
\text { مै }\end{array}$ & $\begin{array}{l}\hat{b} \\
\dot{\omega} \\
\stackrel{+}{\infty}\end{array}$ & \begin{tabular}{l}
$\hat{\sigma}$ \\
$\dot{0}$ \\
\multirow{2}{*}{} \\
$\infty$
\end{tabular} & $\begin{array}{l}\hat{b} \\
\dot{\omega} \\
\stackrel{+}{\ddagger} \\
\infty\end{array}$ & 8 & ৪ু & ৪ু & $\begin{array}{l}8 \\
\text { ○் } \\
\infty \\
\text { बె }\end{array}$ & $\begin{array}{l}0 \\
\dot{\varphi}\end{array}$ \\
\hline
\end{tabular}

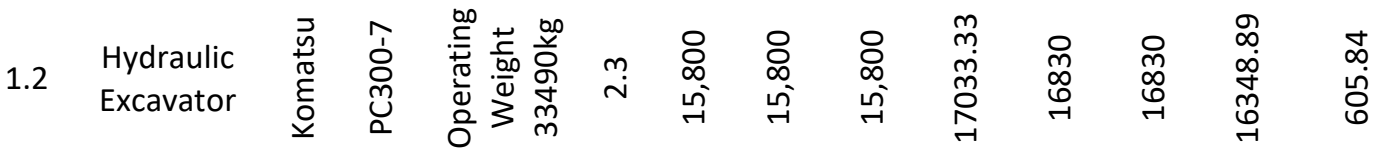

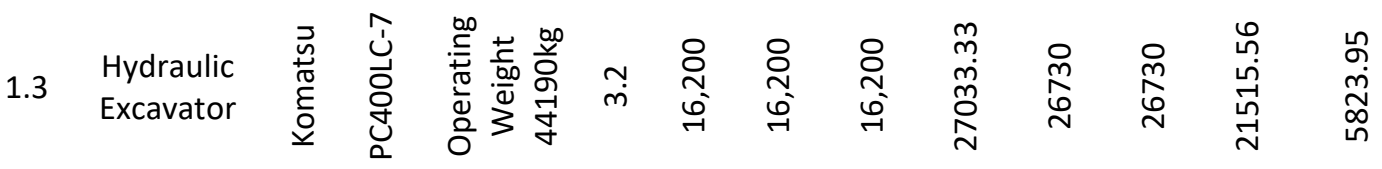

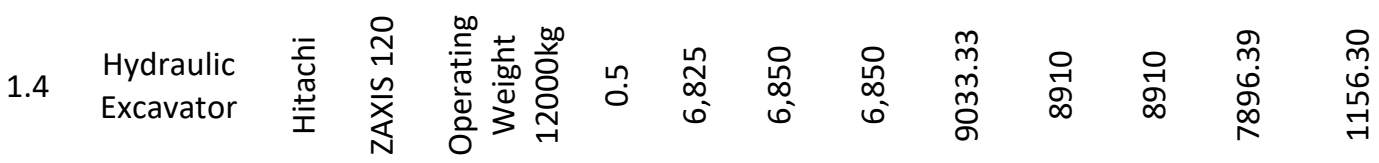

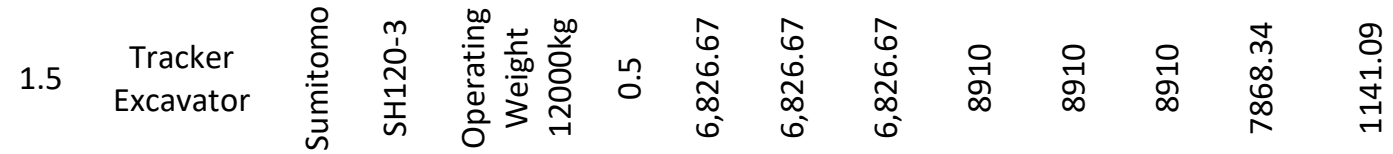

\begin{tabular}{|c|c|c|c|c|c|c|c|c|c|c|c|c|}
\hline \multicolumn{13}{|c|}{ Dozer } \\
\hline Bulldozer & 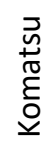 & $\begin{array}{l}\text { フ } \\
\text { ய் } \\
\text { ஸٌ } \\
0\end{array}$ & 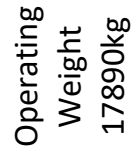 & ' & $\begin{array}{l}8 \\
8 \\
-1 \\
-1\end{array}$ & $\begin{array}{l}8 \\
\stackrel{-}{-1} \\
\underset{-}{-}\end{array}$ & $\begin{array}{l}8 \\
\stackrel{-}{-1} \\
\stackrel{-1}{-1}\end{array}$ & $\begin{array}{l}m \\
m \\
m \\
m \\
\end{array}$ & $\begin{array}{l}\stackrel{0}{m} \\
\infty \\
0 \\
-1\end{array}$ & 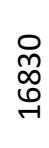 & \begin{tabular}{l}
\multirow{N}{N}{} \\
$\underset{\infty}{N}$ \\
$\underset{\sim}{-}$
\end{tabular} & $\begin{array}{l}\text { ᄋ } \\
\text { ஓं } \\
\text { ले }\end{array}$ \\
\hline
\end{tabular}

\begin{tabular}{|c|c|c|c|c|c|c|c|c|c|c|c|c|c|}
\hline 3 & \multicolumn{13}{|c|}{ Motor Grader } \\
\hline 3.1 & $\begin{array}{l}\text { Motor } \\
\text { Grader }\end{array}$ & 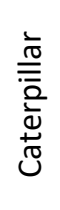 & 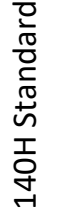 & 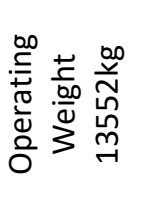 & 1 & $\begin{array}{l}m \\
m \\
m \\
m \\
n \\
\infty \\
\infty\end{array}$ & $\begin{array}{l}\dot{m} \\
m \\
m \\
\ddot{n} \\
\infty\end{array}$ & $\begin{array}{l}\text { ○ } \\
\qquad \\
\infty\end{array}$ & $\begin{array}{l}m \\
m \\
m \\
m \\
\stackrel{n}{N} \\
\end{array}$ & 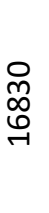 & $\begin{array}{l}0 \\
\text { } \\
\infty \\
0 \\
\qquad \\
-1\end{array}$ & 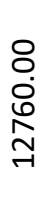 & $\begin{array}{l}m \\
m \\
m \\
m \\
m\end{array}$ \\
\hline
\end{tabular}

\begin{tabular}{|c|c|c|c|c|c|c|c|c|c|c|c|c|c|}
\hline 4 & \multicolumn{13}{|c|}{ Lorry } \\
\hline 4.1 & Lorry & 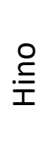 & ' & 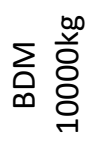 & 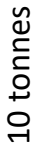 & 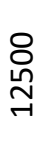 & 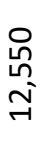 & $\begin{array}{l}8 \\
\text { ठ } \\
\stackrel{-}{-1}\end{array}$ & 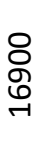 & 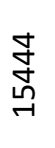 & $\begin{array}{l}\stackrel{\&}{\&} \\
\stackrel{\leftrightarrow}{\sim}\end{array}$ & 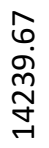 & $\begin{array}{l}\text { ठ } \\
\ddot{0} \\
\text { హે }\end{array}$ \\
\hline
\end{tabular}

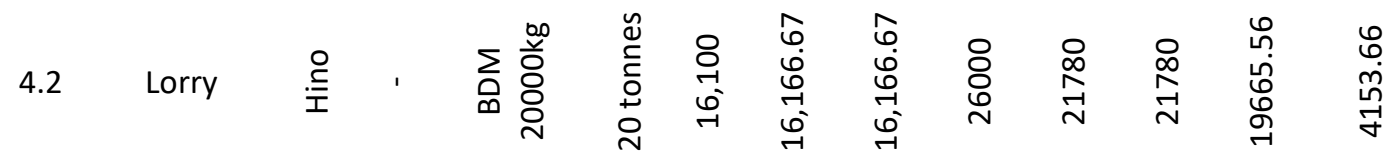




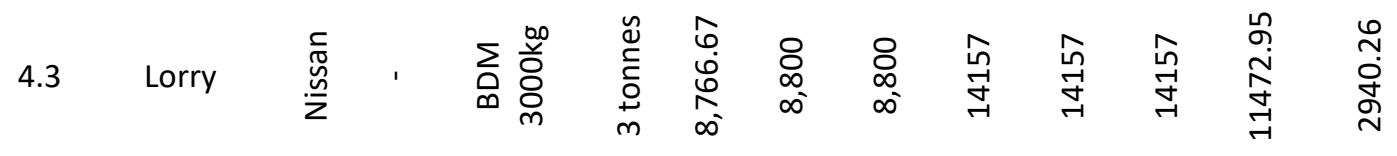

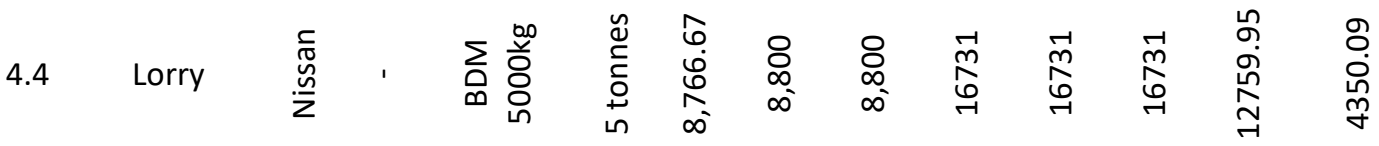

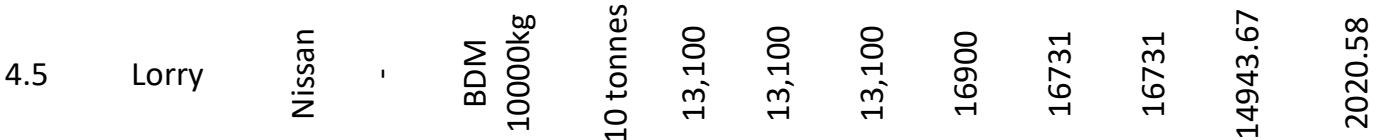

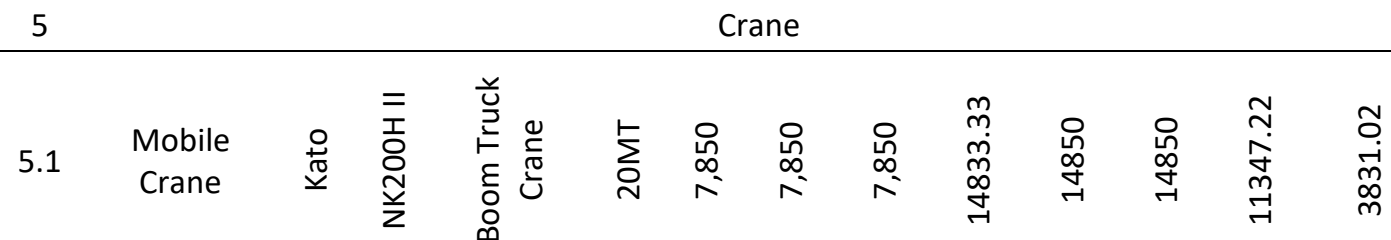

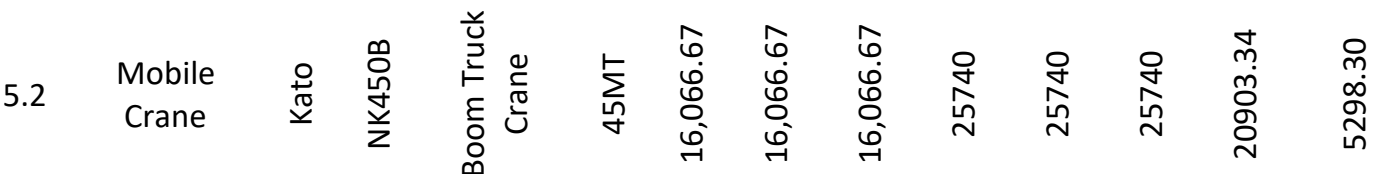

Appendix B. Summary of \% Deviation of Machinery Hire Rates. (Self-Elaboration).

\begin{tabular}{|c|c|c|c|c|c|c|c|c|c|c|}
\hline S.No & $\begin{array}{c}\text { Type of } \\
\text { Machinery }\end{array}$ & Brand & Model & Specification & Capacity & $13-14$ & $14-15$ & $15-16$ & $16-17$ & $17-18$ \\
\hline 1 & \multicolumn{10}{|c|}{ Excavator } \\
\hline 1.1 & $\begin{array}{l}\text { Hydraulic } \\
\text { Excavator }\end{array}$ & Komatsu & PC200-7 & $\begin{array}{l}\text { Operating } \\
\text { Weight } \\
20785 \mathrm{~kg}\end{array}$ & 0.93 & $0 \%$ & $0 \%$ & $19 \%$ & $-1 \%$ & $0 \%$ \\
\hline 1.2 & $\begin{array}{l}\text { Hydraulic } \\
\text { Excavator }\end{array}$ & Komatsu & PC300-7 & $\begin{array}{c}\text { Operating } \\
\text { Weight } \\
33490 \mathrm{~kg}\end{array}$ & 2.3 & $0 \%$ & $0 \%$ & $8 \%$ & $1.19 \%$ & $0 \%$ \\
\hline 1.3 & $\begin{array}{l}\text { Hydraulic } \\
\text { Excavator }\end{array}$ & Komatsu & $\begin{array}{c}\text { PC400LC- } \\
7\end{array}$ & $\begin{array}{c}\text { Operating } \\
\text { Weight } \\
\text { 44190kg }\end{array}$ & 3.2 & $0 \%$ & $0 \%$ & $67 \%$ & $\begin{array}{c}- \\
1.12 \%\end{array}$ & $0 \%$ \\
\hline 1.4 & $\begin{array}{l}\text { Hydraulic } \\
\text { Excavator }\end{array}$ & Hitachi & ZAXIS 120 & $\begin{array}{c}\text { Operating } \\
\text { Weight } \\
12000 \mathrm{~kg}\end{array}$ & 0.5 & $0 \%$ & $0 \%$ & $32 \%$ & $\begin{array}{c}- \\
1.37 \%\end{array}$ & $0 \%$ \\
\hline 1.5 & $\begin{array}{l}\text { Tracker } \\
\text { Excavator }\end{array}$ & Sumitomo & SH120-3 & $\begin{array}{c}\text { Operating } \\
\text { Weight } \\
12000 \mathrm{~kg}\end{array}$ & 0.5 & $0 \%$ & $0 \%$ & $31 \%$ & $0.0 \%$ & $0 \%$ \\
\hline 2 & \multicolumn{10}{|c|}{ Dozer } \\
\hline 2.1 & Bulldozer & Komatsu & D65E-12 & $\begin{array}{c}\text { Operating } \\
\text { Weight } \\
17890 \mathrm{~kg}\end{array}$ & - & $0.91 \%$ & $0 \%$ & $53 \%$ & $\begin{array}{c}- \\
1.19 \%\end{array}$ & $0 \%$ \\
\hline 3 & \multicolumn{10}{|c|}{ Motor Grader } \\
\hline 3.1 & $\begin{array}{l}\text { Motor } \\
\text { Grader }\end{array}$ & Caterpillar & $\begin{array}{c}140 \mathrm{H} \\
\text { Standard }\end{array}$ & $\begin{array}{c}\text { Operating } \\
\text { Weight } \\
13552 \mathrm{~kg}\end{array}$ & - & $0 \%$ & $\begin{array}{c}- \\
0.39 \%\end{array}$ & $98 \%$ & $\begin{array}{c}- \\
1.19 \%\end{array}$ & $0 \%$ \\
\hline 4 & \multicolumn{10}{|c|}{ Lorry } \\
\hline
\end{tabular}




\begin{tabular}{|c|c|c|c|c|c|c|c|c|c|c|}
\hline 4.1 & Lorry & Hino & - & $\begin{array}{c}\text { BDM } \\
10000 \mathrm{~kg}\end{array}$ & $\begin{array}{c}10 \\
\text { tonnes }\end{array}$ & $0.40 \%$ & $0 \%$ & $34 \%$ & $-9 \%$ & $0 \%$ \\
\hline 4.2 & Lorry & Hino & - & $\begin{array}{c}\text { BDM } \\
20000 \mathrm{~kg}\end{array}$ & $\begin{array}{c}20 \\
\text { tonnes }\end{array}$ & $0.41 \%$ & $0 \%$ & $61 \%$ & $-16 \%$ & $0 \%$ \\
\hline 4.3 & Lorry & Nissan & - & BDM $3000 \mathrm{~kg}$ & 3 tonnes & $0.38 \%$ & $0 \%$ & $61 \%$ & $0 \%$ & $0 \%$ \\
\hline 4.4 & Lorry & Nissan & - & BDM 5000kg & 5 tonnes & $0.38 \%$ & $0 \%$ & $90 \%$ & $0 \%$ & $0 \%$ \\
\hline 4.5 & Lorry & Nissan & - & $\begin{array}{c}\text { BDM } \\
10000 \mathrm{~kg}\end{array}$ & $\begin{array}{c}10 \\
\text { tonnes }\end{array}$ & $0 \%$ & $0 \%$ & $29 \%$ & $-1 \%$ & $0 \%$ \\
\hline 5 & \multicolumn{10}{|c|}{ Crane } \\
\hline 5.1 & $\begin{array}{l}\text { Mobile } \\
\text { Crane }\end{array}$ & Kato & $\mathrm{NK} 200 \mathrm{H} \mathrm{II}$ & $\begin{array}{l}\text { Boom Truck } \\
\text { Crane }\end{array}$ & 20MT & $0 \%$ & $0 \%$ & $89 \%$ & $0 \%$ & $0 \%$ \\
\hline 5.2 & $\begin{array}{c}\text { Mobile } \\
\text { Crane }\end{array}$ & Kato & NK450B & $\begin{array}{c}\text { Boom Truck } \\
\text { Crane }\end{array}$ & $45 \mathrm{MT}$ & $0 \%$ & $0 \%$ & $60 \%$ & $0 \%$ & $0 \%$ \\
\hline
\end{tabular}

\section{Acknowledgements}

The authors would like to thank to University Technology PETRONAS (UTP) for the support provided for this research.

Rahman, A., \& Rozaini, N. (2020). Project Risk Based Evaluation for Infrastructure Works in Qatar: Highway Projects. Proceedings of the International Conference on Civil Infrastructure and Construction (CIC 2020), Qatar University, Doha, Qatar, 2-5 February, 2020.

Rahman, I. A., Memon, A. H., Nagapan, S., Latif, Q. B. A. I., \& Azis, A. A. A. Time and cost performance of costruction projects in southern and cenrtal regions of Penisular Malaysia. 2012 IEEE Colloquium on Humanities, Science and Engineering (CHUSER) (pp. 52-57), IEEE, Kota Kinabalu, Malaysia, 3-4 December, 2012.

Alaloul, W. S., Liew, M. S., Zawawi, N. A. W. A., \& Kennedy, I. B. (2020). Industrial Revolution 4.0 in the construction industry: Challenges and opportunities for stakeholders. Ain shams engineering journal, 11(1), 225-230.

Alaloul, W. S., Liew, M. S., Zawawi, N. A. W., Mohammed, B. S., Adamu, M., \& Musharat, M. A. (2020). Structural equation modelling of construction project performance based on coordination factors. Cogent Engineering, 7(1), 1726069.

Alaloul, W. S., Musarat, M. A., Liew, M. S., Qureshi, A. H., \& Maqsoom, A. (2021). Investigating the impact of inflation on labour wages in Construction Industry of Malaysia. Ain Shams Engineering Journal. In press.

Alaloul, W. S., Musarat, M. A., Liew, M. S., \& Zawawi, N. A. W. A. (2019, August). Influential safety performance and assessment in construction projects: a review. AWAM International Conference on Civil Engineering (pp. 719-728). Conference proceedings AICCE 2019. Springer, Cham.

Alinaitwe, H., Apolot, R., \& Tindiwensi, D. (2013). Investigation into the causes of delays and cost overruns in Uganda's public sector construction projects. Journal of Construction in Developing Countries, 18(2), 33.

Aljohani, A. (2019). Cost overrun causality model in Saudi Arabian public sector construction projects (Doctoral dissertation).

Aljohani, A., Ahiaga-Dagbui, D., \& Moore, D. (2017). Construction projects cost overrun: What does the literature tell us?. International Journal of Innovation, Management and Technology, 8(2), 137.

Altaf, M., Musarat, M. A., Khan, A., Shoukat, Z., \& Salahuddin, U. Change order impact on construction industry of Pakistan. AWAM International Conference on Civil Engineering (pp. 391-402). Conference proceedings AICCE 2019. LNCE, Volume 53. Springer, Cham.

Amusan, L. M., Afolabi, A., Ojelabi, R., Omuh, I., \& Okagbue, H. I. (2018). Data exploration on factors that influences construction cost and time performance on construction project sites. Data in brief, 17, 1320-1325.

Assaad, R., El-Adaway, I. H., \& Abotaleb, I. S. (2020). Predicting Project Performance in the Construction Industry. Journal of Construction Engineering and Management, 146(5), 04020030.

Aziz, R. F. (2013). Factors causing cost variation for constructing wastewater projects in Egypt. Alexandria Engineering Journal, 52 (1), 51-66.

Bayram, S., \& Al-Jibouri, S. (2016). Efficacy of estimation methods in forecasting building projects' costs. Journal of Construction Engineering and Management, 142(11), 05016012.

Catalão, F. P., Cruz, C. O., \& Sarmento, J. M. (2019). The determinants of cost deviations and overruns in transport projects, an endogenous models approach. Transport Policy, 74, 224-238.

Endut, I. R., Akintoye, A., \& Kelly, J. (2009). Cost and time overruns of projects in Malaysia. retrieved on August, 21, $243-252$.

Enshassi, A., Al-Najjar, J., \& Kumaraswamy, M. (2009a). Delays and cost overruns in the construction projects in the Gaza Strip. Journal of Financial Management of Property and Construction, 14(2), 126-151. 
Enshassi, A., Al-Najjar, J., \& Kumaraswamy, M. (2009b). Delays and cost overruns in the construction projects in the Gaza Strip. Journal of Financial Management of property and Construction, 14(2), 126-151. https://doi.org/10.1108/13664380910977592

Erusta, N. E., \& Sertyesilisik, B. (2019, May). An Investigation into Improving Occupational Health and Safety Performance of Construction Projects Through Usage of BIM for Lean Management. Eurasian BIM Forum (pp. 91-100). Springer, Cham.

Firouzi, A., Yang, W., \& Li, C.-Q. (2016). Prediction of total cost of construction project with dependent cost items. Journal of Construction Engineering and Management, 142(12), 04016072.

Fulton, B. (2019). Interpreting Correlations. Interpreting Correlations. Retrieved from https://www.staymetrics.com/2019/09/interpretingcorrelations/

Goyal, S. (2017). Effect of inflation on project costs in Rajasthan. Proceedings of SARC-CAN International Conference. University Rajasthan, New Delhi, India, $12^{\text {th }}$ March, 2017.

Haslinda, A. N., Xian, T. W., Norfarahayu, K., Hanafi, R. M., \& Fikri, H. M. (2018, April). Investigation on the factors influencing construction time and cost overrun for high-rise building projects in penang. Journal of Physics: Conference Series (Vol. 995, No. 1, p. 012043). IOP Publishing.

Jaya, I., Alaloul, W. S., \& Musarat, M. A. (2021). Role of Inflation in Construction: A Systematic Review. In Proceedings of the International Conference on Civil, Offshore and Environmental Engineering (pp. 701-708). Springer, Singapore.

Johnson, R. M., \& Babu, R. I. I. (2020). Time and cost overruns in the UAE construction industry: a critical analysis. International Journal of Construction Management, 20(5), 402-411. https://doi.org/10.1080/15623599.2018.1484864

Kaliba, C., Muya, M., \& Mumba, K. (2009). Cost escalation and schedule delays in road construction projects in Zambia. International journal of project management, 27(5), 522-531.

Khodeir, L. M., \& El Ghandour, A. (2019). Examining the role of value management in controlling cost overrun [application on residential construction projects in Egypt]. Ain Shams Engineering Journal, 10(3), 471-479.

Klakegg, O. J., \& Lichtenberg, S. (2016). Successive cost estimation-successful budgeting of major projects. Procedia-Social and Behavioral Sciences, $226,176-183$

Kornbrot, D. (2005). S pearman's Rho. Encyclopedia of Statistics in Behavioral Science.

Le-Hoai, L., Dai Lee, Y., \& Lee, J. Y. (2008). Delay and cost overruns in Vietnam large construction projects: A comparison with other selected countries. KSCE journal of civil engineering, 12(6), 367-377. https://doi.org/10.1007/s12205-008-0367-7

Le, N., Chong, O., \& Sullivan, K. (2020). Construction Risks in Developing Countries: A Vietnam Case Study. Journal for the Advancement of Performance Information and Value, 12(1), 30-49.

Leavitt, D., Ennis, S., \& McGovern, P. (1993). The cost escalation of rail projects: Using previous experience to re-evaluate the CalSpeed estimates (Working Paper No. 567). Berkeley: University of California, Berkeley, Institute of Urban and Regional Development.

Mashwama, X., Aigbavboa, C., \& Thwala, D. (2016). Investigation of construction stakeholders' perception on the effects \& cost of construction dispute in Swaziland. Procedia engineering, 164, 196-205.

Memon, A. H., Abdul Rahman, I., Aziz, A., \& Asmi, A. (2014). Assessing causal relationships between construction resources and cost overrun using PLS path modelling focusing in Southern and Central Region of Malaysia. Journal of Engineering and Technology, 4(1), 67-68.

Memon, A. H., Rahman, I. A., Zainun, N. Y., \& Abd Karim, A. T. (2014). Web-based risk assessment technique for time and cost overrun (WRATTCO)A framework. Procedia-Social and Behavioral Sciences, 129, 178-185.

Minitab. A comparison of the Pearson and Spearman correlation methods. Retrieved from https://support.minitab.com/en-us/minitabexpress/1/help-and-how-to/modeling-statistics/regression/supporting-topics/basics/a-comparison-of-the-pearson-and-spearman-correlationmethods/

Musarat, M. A., \& Ahad, M. Z. (2016). Factors Affecting the Success of Construction Projects in Khyber Pakhtunkhwa, Pakistan. Journal of Construction Engineering and Project Management, 6(4), 1-6.

Musarat, M. A., Alaloul, W. S., \& Liew, M. (2020a). Impact of inflation rate on construction projects budget: A review. Ain Shams Engineering Journal, 12(1), 407-414.

Musarat, M. A., Alaloul, W. S., Liew, M. S., Maqsoom, A., \& Qureshi, A. H. (2020). Investigating the impact of inflation on building materials prices in construction industry. Journal of Building Engineering, 32, 101485

Musarat, M. A., Alaloul, W. S., Liew, M., Maqsoom, A., \& Qureshi, A. H. (2021). The Effect of Inflation Rate on CO2 Emission: A Framework for Malaysian Construction Industry. Sustainability, 13(3), 1562.

Musarat, M. A., Alaloul, W. S., Qureshi, A. H., \& Altaf, M. (2020, November). Inflation Rate and Construction Materials Prices: Relationship Investigation. In 2020 International Conference on Decision Aid Sciences and Application (DASA) (pp. 387-390). IEEE.

Musarrat, M. A., Inderyas, O., Khan, S., \& Shah, A. A. (2017). Causes of delay in the execution phase of construction projects in khyber pukhtoonkhwa pakistan. Sarhad University International Journal of Basic and Applied Sciences, 4(1), 62-70.

National Construction Cost Centre (N3C). (2019). Machinery Hire Rates. from CIDB, Malaysia http://myn3c.cidb.gov.my/cidb_n3c/output/a_web_mne_details.php?4

Niazi, G. A., \& Painting, N. (2017). Significant factors causing cost overruns in the construction industry in Afghanistan. Procedia Engineering, 182, 510517. 
Oghenekevwe, O., Olusola, O., \& Chukwudi, U. S. (2014). An assessment of the impact of inflation on construction material prices in Nigeria. PM World Journal, 3(4), 1-22.

Olawale, Y. A., \& Sun, M. (2010). Cost and time control of construction projects: inhibiting factors and mitigating measures in practice. Construction management and economics, 28(5), 509-526.

Paraskevopoulou, C., \& Benardos, A. (2013). Assessing the construction cost of Greek transportation tunnel projects. Tunnelling and underground space technology, 38, 497-505.

Paul, V. K., \& Saigal, D. Cost Overrun Risks in Infrastructure Projects: Case of Hydroelectric Projects. Journal of Civil Engineering and Environmental Technology, 6(2), 68-74.

Ranjithapriya, R., \& Arulselvan, S. Study on Factors Affecting Equipment Management and its Effect on Productivity in Building Construction. International Journal of Engineering Research \& Technology (IJERT), 9(4), 223-230.

Rashid, Y. (2020). Analysis of delay factors and their effects on construction projects. Management Science Letters, 10(6), 1197-1204.

Samuel, M., \& Okey, L. (2015). The relevance and significance of correlation in social science research. International Journal of Sociology and Anthropology Research, 1(3), 22-28.

Shehu, Z., Endut, I. R., Akintoye, A., \& Holt, G. D. (2014). Cost overrun in the Malaysian construction industry projects: A deeper insight. International Journal of Project Management, 32(8), 1471-1480.

Sohu, S., Abdullah, A. H., Nagapan, S., Buriro, A. A., \& Ullah, K. (2018). Stakeholders' Perception on Critical Cost Variation Factors in Malaysian Building Projects. Civil Engineering Journal, 4(9), 2075-2081.

Statista. (2019). Malaysia: Inflation rate from 1984 to 2024. Retrieved from https://www.statista.com/statistics/319033/inflation-rate-in-malaysia/

Tang, C. F. (2014). The effect of real wages and inflation on labour productivity in Malaysia. International review of applied economics, $28(3), 311-322$. 